\title{
65 Lat działalności OSŻD w przestrzeni euroazjatyckiej
}

\author{
Mirosław ANTONOWICZ1
}

\begin{abstract}
Streszczenie
Organizacja Współpracy Kolei (OSŻD) jest międzynarodową organizacją stworzoną na podstawie międzynarodowej umowy „Przepisy o Organizacji Współpracy Kolei”. Rok 2021 jest znaczący dla OSŻD, ponieważ Organizacja obchodzi jubileusz 65-lecia istnienia. Minione lata były okresem ciągłego rozwoju OSŻD obfitującego w ważne wydarzenia i zmiany zarówno w samej Organizacji, jak i w ekonomicznej i geopolitycznej sytuacji na terytorium objętym jej działalnością. OSŻD sukcesywnie dąży do rozwoju i usprawnienia przewozów kolejowych w przestrzeni euroazjatyckiej przez rozwój i doskonalenie międzynarodowych korytarzy transportowych i unifikację prawa transportowego. Jest jedną z ważniejszych organizacji w obszarze zagadnień kolejowych funkcjonujących w świecie. Aktywnie działa i współpracuje z innymi ważnymi organizacjami międzynarodowymi działającymi w obszarze transportu kolejowego, jak np. Międzynarodowy Związek Kolejowy (UIC), Międzynarodowy Komitet Transportu Kolejowego (CIT), Międzyrządowa Organizacja Międzynarodowych Przewozów Kolejami (OTIF), których zadaniem jest dążenie do promocji, współpracy, rozwoju, usprawniania i ułatwiania międzynarodowego transportu kolejowego jako środka transportu mogącego sprostać wyzwaniom mobilności oraz zrównoważonego rozwoju. W ramach tej współpracy, OSŻD zmierza do ciągłego doskonalenia przewozów kolejowych przez upraszczanie procedur granicznych i harmonizację dokumentów przewozowych, czego przykładem jest wspólny list przewozowy CIM/SMGS. Celem artykułu jest wskazanie podstawowych zadań i roli organizacji w rozwoju transportu kolejowego w przestrzeni euroazjatyckiej na przestrzeni ostatnich lat.
\end{abstract}

Słowa kluczowe: OSŻD, transport kolejowy, organizacje międzynarodowe, przestrzeń euroazjatycka, list przewozowy

\section{Wstęp}

Zmiana warunków politycznych w Europie i Azji po II wojnie światowej oraz rosnąca tendencja wymiany towarowej i pasażerskiej między krajami bloku wschodniego, spowodowała konieczność stworzenia jednolitych podstaw prawnych oraz ekonomicznych dla organizacji międzynarodowej towarowej i pasażerskiej komunikacji kolejowej. Powstanie OSŻD poprzedziły intensywne prace przygotowawcze. $\mathrm{W}$ rezultacie, w 1951 roku opracowano oraz uzgodniono pierwsze normatywne dokumenty regulujące prowadzenie przewozów pasażerskich i towarowych w międzynarodowej komunikacji kolejowej. Były to:

1. Umowa o przewozie osób i bagażu kolejami w bezpośredniej komunikacji międzynarodowej (MPS) oraz Instrukcja Służbowa do Umowy.

2. Umowa o przewozie towarów kolejami w bezpośredniej komunikacji międzynarodowej (MGS), a także Instrukcja Służbowa do Umowy.
3. Taryfa przewozowa osób, bagażu i przesyłek ekspresowych kolejami w bezpośredniej komunikacji międzynarodowej.

4. Jednolita Tranzytowa Taryfa przewozowa towarów przez kraje uczestniczące w Umowie o przewozie towarów kolejami w bezpośredniej komunikacji międzynarodowej (MGS).

5. Przepisy o wzajemnym użytkowaniu wagonów w komunikacji międzynarodowej (ППВ).

6. Przepisy o rozliczeniach do Umów MPS i MGS.

Wymienione umowy, przepisy oraz taryfy wdrożono 1 listopada 1951 roku. Prowadzenie umów MPS i MGS powierzono Polskim Kolejom Państwowym, które do realizacji tego zadania powołały Biuro Zarządzające MPS-MGS z siedzibą w Warszawie. Po kilku latach teksty tych dokumentów zasadniczo zmieniono oraz nadano inne nazwy: SMGS (Umowa o międzynarodowej komunikacji osobowej) i SMGS (Umowa o międzynarodowej komunikacji towarowej).

\footnotetext{
${ }^{1}$ Prof. Akademii Leona Koźmińskiego, dr; Katedra Marketingu, Centrum Logistyki i Łańcuchów Dostaw Akademii Leona Koźmińskiego, Przewodniczący Organizacji Współpracy Kolei (OSŻD); e-mail: maaw@kozminski.edu.pl.
} 
Wzrosła także liczba sygnatariuszy tych Umów. Z biegiem czasu współpraca między kolejami zacieśniała się, znacząco wzrosły także wielkości przewozów pasażerskich i towarowych, co pociągnęło za sobą konieczność rozszerzenia współpracy na kolejne dziedziny działalności kolei. Zaistniała konieczność stworzenia nowej struktury wyższego szczebla, która sprostałaby nowym wyzwaniom dzięki kompleksowemu podejściu do działalności kolejowej. Do sprawnego zarządzania i sprawowania bezpośredniej kontroli nad spójnością międzynarodowej komunikacji kolejowej, należało powołać organ kierowniczy wysokiego szczebla określający politykę i strategię w zakresie transportu kolejowego. W czerwcu 1956 roku, w Sofii odbyła się Narada Ministrów odpowiedzialnych za transport kolejowy w $10 \mathrm{krajach}^{2}$. Było to pierwsze posiedzenie najwyższego organu kierowniczego OSŻD, na którym podjęto decyzję o utworzeniu Organizacji Współpracy Kolei. Jako organ wykonawczy, pełniący rolę depozytariusza wszystkich umów zawieranych w ramach OSŻD, powołano Komitet OSŻD z siedzibą w Warszawie.

\section{Podstawowe cele, zadania i kierunki działalności OSŻD [1]}

Podczas swojego istnienia, OSŻD skupiała się na strategicznym celu polityki transportowej, jakim jest rozwój międzynarodowej komunikacji kolejowej, w tym transport kombinowany między Europą i Azją oraz zwiększenie konkurencyjności i efektywności transportu kolejowego. Polityka krajów członkowskich OSŻD jest ukierunkowana na utrzymanie i wzmocnienie pozycji transportu kolejowego na międzynarodowych rynkach usług przewozowych oraz zapewnienie stabilnej międzynarodowej wymiany handlowej. Ważna jest także integracja kolei krajów członkowskich OSŻD ze światowym systemem transportowym we wspólnej przestrzeni transportowej przez skierowanie wysiłków na rozwiązywanie nie tylko kwestii ogólnych, lecz także pokonywanie trudności na różnorodnych kierunkach przewozowych, korytarzach transportowych oraz na konkretnych przejściach granicznych. Podstawowymi kierunkami działalności OSŻD są następujące działania:

- rozwój międzynarodowej komunikacji kolejowej między krajami Europy i Azji, włączając w to transport kombinowany;

- współpraca dotycząca polityki transportowej oraz prawnych i ekologicznych aspektów transportu kolejowego;

- prowadzenie umów: SMGS (Umowa o międzynarodowej komunikacji osobowej) i SMGS (Umowa o międzynarodowej komunikacji towarowej), Umowy o Przepisach dotyczących użytkowania wagonów towarowych w komunikacji międzynarodowej (PGW), Umowy o Przepisach dotyczących użytkowania wagonów pasażerskich w komunikacji międzynarodowej (PPW), Umowy o Międzynarodowej pasażerskiej taryfie przewozowej (MPT), Umowy o Jednolitej Taryfie Tranzytowej (ETT), Umowy o Międzynarodowej Taryfie Tranzytowej (MTT), Umowy o Przepisach rozliczeniowych $\mathrm{w}$ międzynarodowej komunikacji osobowej i towarowej oraz innych prawnych i normatywno-technicznych dokumentów, mających zastosowanie w komunikacji międzynarodowej;

- formułowanie ogólnych zasad jednolitego, międzynarodowego prawa przewozowego w zakresie transportu kolejowego;

- wypracowywanie działań na rzecz zwiększenia konkurencyjności kolei w stosunku do innych rodzajów transportu;

- rozwój współpracy na rzecz ulepszenia przepisów dotyczących eksploatacji oraz modernizacji linii kolejowych, na których prowadzone są przewozy międzynarodowe oraz warunków technicznych na tych liniach;

- udział w rozwiązywaniu problemów dotyczących współpracy międzynarodowej, w której uczestniczą koleje OSŻD;

- współpraca z innymi organizacjami międzynarodowymi o tym samym lub zbliżonym profilu działania ${ }^{3}$.

W tym kontekście organizacja OSŻD jawi się, jako podstawa komunikacji kolejowej między Europą i Azją w XXI wieku, łącząc systemy prawa kolejowego oraz różne systemy szerokości toru.

\footnotetext{
${ }^{2}$ W naradzie uczestniczyli ówcześni przedstawiciele z krajów: Ludowej Republiki Bułgarii, Węgierskiej Republiki Ludowej, Niemieckiej Republiki Demokratycznej, Chińskiej Republiki Ludowej, Koreańskiej Republiki Ludowo-Demokratycznej, Mongolskiej Republiki Ludowej, Polskiej Rzeczpospolitej Ludowej, Rumuńskiej Republiki Ludowej, Związku Socjalistycznych Republik Radzieckich i Czechosłowackiej Republiki Socjalistycznej.

${ }^{3}$ Oprócz wymienionych działań, OSŻD aktywnie współpracuje w zakresie transportu kolejowego z wieloma organizacjami rządowymi i pozarządowymi, takimi jak: EKG ONZ, ESKAP ONZ, DG MOVE, EAES (Euroazjatycki Związek Ekonomiczny), UIC, ERA, CCTT, FIATA, FTE, UPU, CTC, TMTM (Middle Corridor), ECO, CSZT (Rada ds. transportu kolejowego WNP), UITP, FERRMED. Współpraca z tymi organizacjami jest bardzo owocna w sferze międzynarodowej komunikacji kolejowej oraz umożliwia poszerzenie zakresu realizowanych działań i zadań.
} 


\section{Członkowie i struktura organizacji [2]}

Obecnie, organizacja OSŻD obejmuje swym zasięgiem przestrzeń terytorialną o powierzchni $37,5 \mathrm{mln} \mathrm{km}{ }^{2}$ zamieszkaną przez ponad 2 mld ludzi. Sieć kolejowa krajów członkowskich OSŻD liczy około 300 tys. km linii kolejowych, po których rocznie przewozi się ponad 5,5 mld ( $\mathrm{z}$ wyłączeniem sytuacji kryzysowej związanej z COVID-19) pasażerów i 5,6 mld ton ładunków.
Długość eksploatacyjna wszystkich linii kolejowych krajów członkowskich OSŻD w chwili powoływania Organizacji do życia wynosiła około 227 tys. km. Dynamikę zmian długości linii kolejowych w krajach członkowskich OSŻD w ostatnich latach przedstawia rysunek 1 . W wyniku zmian geopolitycznych liczba krajów członkowskich OSŻD wrosła i organizacja zrzesza obecnie 29 krajów (w 2018 roku członkiem organizacji została Korea Południowa $)^{4}$, co przedstawia rysunek 2.
Rys. 1. Dynamika zmian długości linii kolejowych i linii zelektryfikowanych (lewa strona wykresu dotyczy zmian w liniach zelektryfikowanych, a prawa zmian w całkowitej długości linii) [10]
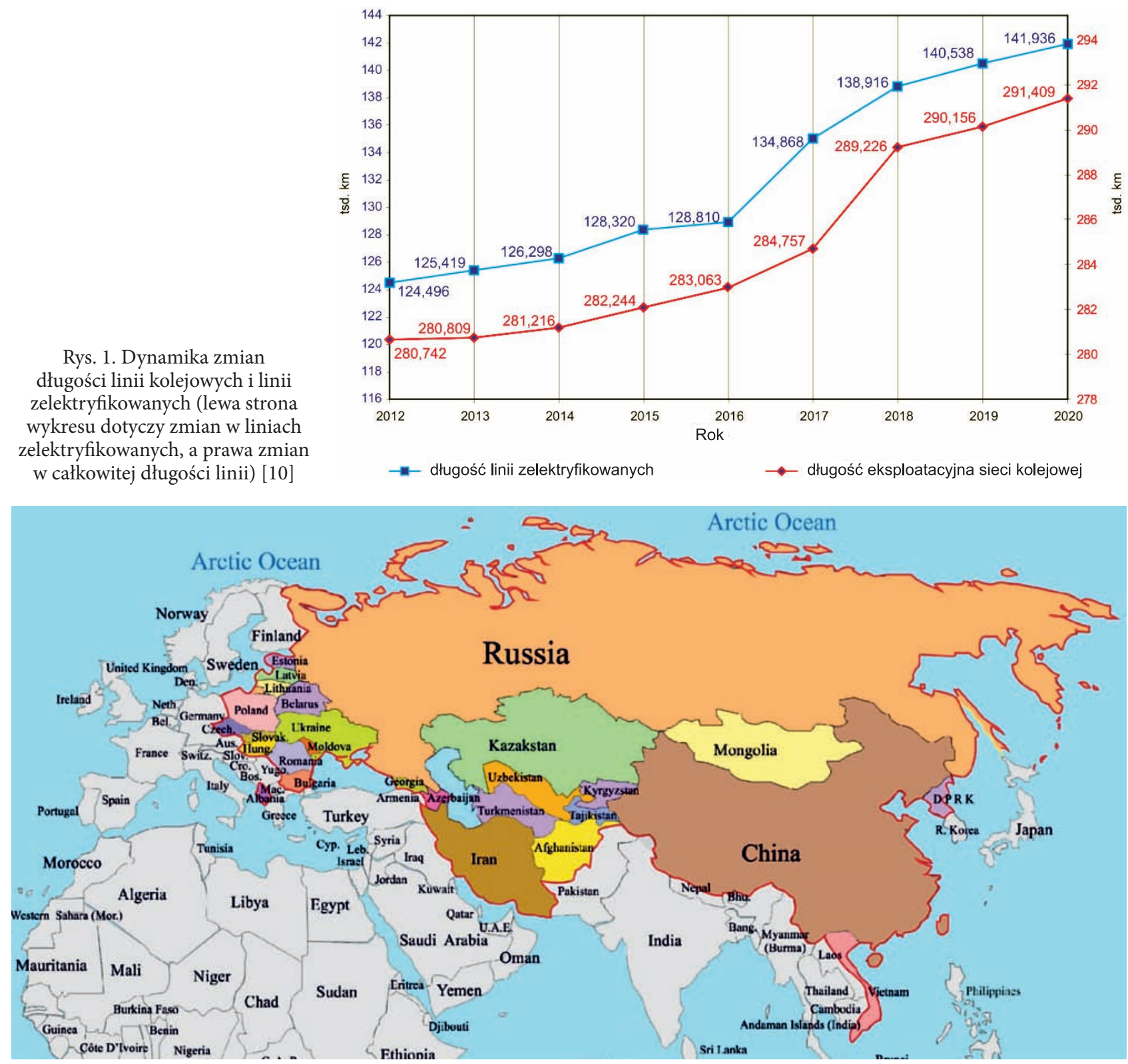

Rys. 2. Członkowie organizacji OSŻD [10]

\footnotetext{
${ }^{4}$ Są to następujące kraje: Republika Azerbejdżanu, Republika Albanii, Islamskie Państwo Afganistanu, Republika Białorusi, Republika Bułgarii, Węgry, Socjalistyczna Republika Wietnamu, Gruzja, Islamska Republika Iranu, Republika Kazachstanu, Chińska Republika Ludowa, Koreańska Republika Ludowo-Demokratyczna, Republika Korei, Republika Kuby, Republika Kirgiska, Republika Łotewska, Republika Litewska, Republika Mołdawii, Mongolia, Rzeczpospolita Polska, Federacja Rosyjska, Rumunia, Republika Słowacka, Republika Tadżykistanu, Turkmenistan, Republika Uzbekistanu, Ukraina, Republika Czeska, Republika Estońska.
} 
Obecnie trwają prace związane z przyjęciem do organizacji kolejnych członków. Dodatkowo, m.in. koleje niemieckie, koleje fińskie, Federalna Kompania Pasażerska (FPK Rosja) mają status obserwatora w OSŻD. Status przedsiębiorstw stowarzyszonych mają również liczne przedsiębiorstwa, instytuty i organizacje $\mathrm{z}$ krajów kontynentu euroazjatyckiego, których działalność jest związana z transportem kolejowym. W styczniu 2021 roku było 40 członków i ich liczba stale rośnie, a chęć przystąpienia do stowarzyszenia deklarują kolejne przedsiębiorstwa ${ }^{5}$. W strukturze organizacji najważniejszą władzą jest Narada Ministrów i Konferencja Dyrektorów Generalnych Kolei Państw członków OSŻD ${ }^{6}$.

Strukturę organizacji przedstawiono na rysunku 3. W okresach między sesjami organów kierujących, prace organizacji koordynuje Komitet OSŻD jako organ wykonawczy. Organami roboczymi OSŻD jest pięć Komisji i dwie Stałe Grupy Robocze (PRG). Komisja

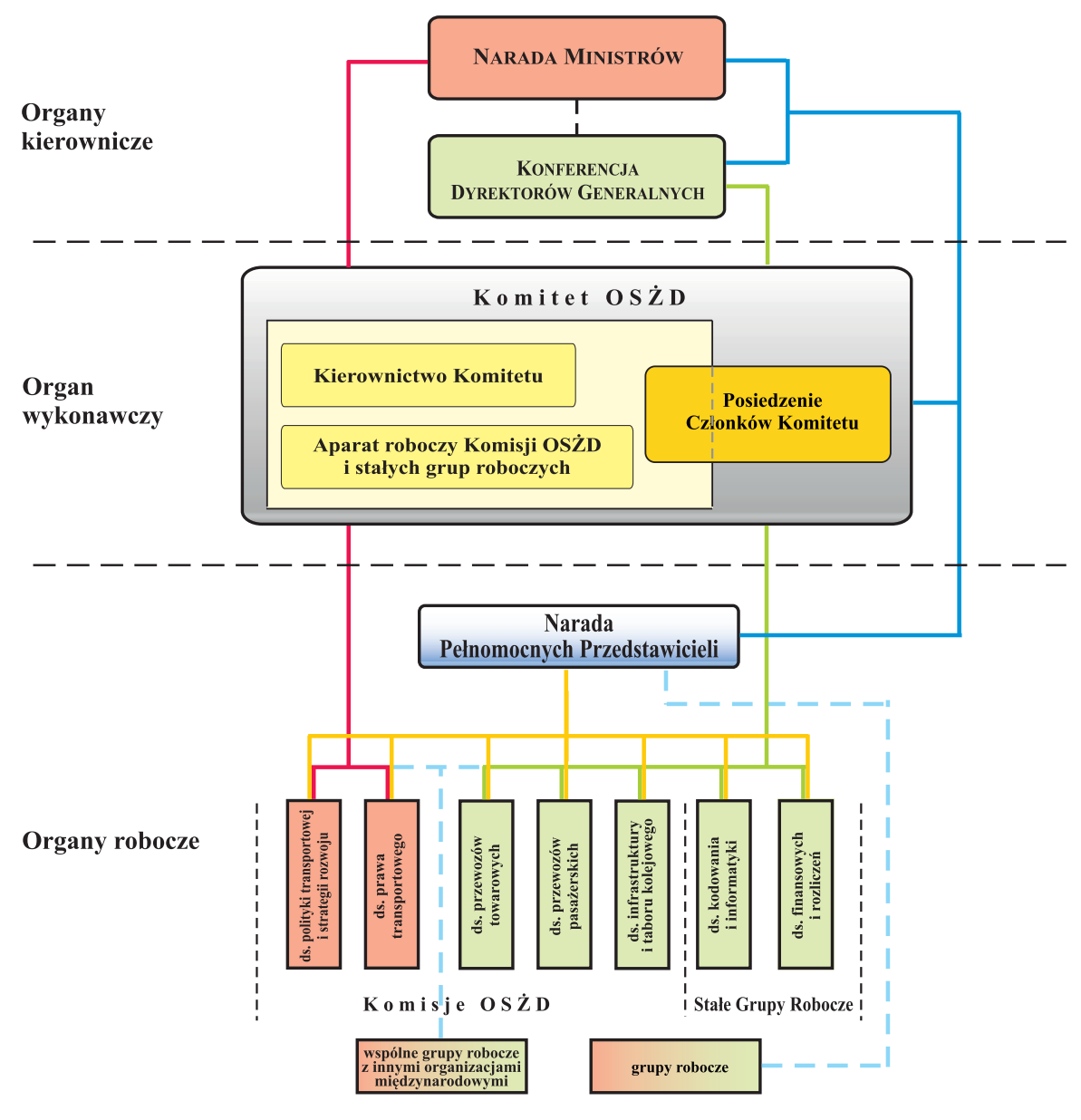

Uczestnicy w ramach wspótpracy OSŻD
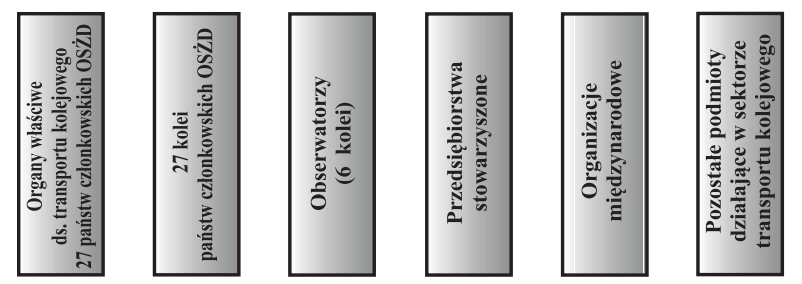

Rys. 3. Struktura organizacji OSŻD [6]

\footnotetext{
${ }^{5}$ W kwietniu 2021 roku, na posiedzeniu Konferencji Generalnych Dyrektorów Kolei przyjęto kolejne przedsiębiorstwa, np. z Austrii, Czech, Węgier i Polski.

${ }^{6} \mathrm{~W}$ związku ze strukturalnymi zmianami na kolejach wielu krajów członkowskich OSŻD oraz pojawieniem się przedsiębiorstw kolejowych, jako samodzielnych podmiotów gospodarczych, w 1992 roku na XX posiedzeniu Narady Ministrów w Ułan-Bator (Mongolia) podjęto decyzję o powołaniu organu kierowniczego OSŻD na szczeblu przedsiębiorstw kolejowych - Konferencji Dyrektorów (pełnomocnych przedstawicieli) Kolei OSŻD.
} 
składa się z wielu Grup Roboczych o charakterze czasowym oraz Wspólnych Grup Roboczych tworzonych z innymi organizacjami. Przykładowe Grupy Robocze o charakterze czasowym są następujące:

1. Grupa robocza ds. przygotowania / dokształcania zawodowego w zakresie przewozów kolejowych;

2. Grupa robocza o profilu „Przewozy Ładunków Niebezpiecznych", działająca w ramach Komisji OSŻD ds. prawa transportowego;

3. Grupa robocza o profilu „Komunikacja kolejowo-wodna”, działająca w ramach Komisji OSŻD ds. prawa transportowego.

W organizacji przywiązuje się dużo uwagi do współpracy $\mathrm{z}$ innymi międzynarodowymi organizacjami w ramach wspólnych eksperckich grup roboczych współpracujących z międzynarodowymi organizacjami między innymi: z Grupą kontaktową OSŻD/ERA na temat: „Współpraca między ERA i OSŻD w zakresie kwestii współdziałania między kolejowymi systemami krajów członków i krajów nie będących członkami UE z systemami kolejowymi o szerokościach torów $1520 \mathrm{~mm}, 1524 \mathrm{~mm}$ i $1435 \mathrm{~mm}$; Wspólną grupą roboczą (prawną) CIT-OSŻD ds. harmonizacji prawa przewozowego CIM/SNGS; Wspólną grupą roboczą OSŻD/UIC „Kodowanie i Informatyka"; grupą roboczą OSŻD/UIC zainteresowanych przedsiębiorstw kolejowych ds. przekształcenia wspólnych priorytetowych fiszek OSŻD/UIC w Międzynarodowe techniczne rozwiązania OSŻD/UIC ze statusem dokumentów z dobrowolnym akcesem. Jest to niezwykle ważne, ponieważ połączenia kolejowe między krajami członkowskimi OSŻD charakteryzują się znacznymi odległościami (8-12 tys. km), różnymi strefami klimatycznymi ( $w$ tym również strefą klimatu surowego) oraz dwukrotną zmianą szerokości toru przy pokonywaniu trasy w jednym kierunku (1435 mm, $1520 \mathrm{~mm}, 1435 \mathrm{~mm}$ ).

W przewozach między Europą i Azją bierze udział znaczna liczba krajów o różnych systemach prawnych w zakresie transportu kolejowego. Dokumenty opracowywane i przyjmowane $w$ ramach OSŻD, zapewniają jednolite prawne pole działania międzynarodowej komunikacji kolejowej między krajami członkowskimi OSŻD. Wymaga ono doskonalenia i uzgodnień m.in. w takich dziedzinach jak warunki przewozowe, taryfy, procedury celne, zasady wzajemnego korzystania $\mathrm{z}$ wagonów, wsparcie informacyjno-technologiczne, rozliczenia finansowe między kolejami. W związku z tym, OSŻD prowadzi systematyczną pracę na rzecz rozwoju międzynarodowych przewozów kolejami, włączając transport kombinowany w komunikacji między Europą i Azją oraz na rzecz zwiększenia konkurencyjności i atrakcyjności transportu kolejowego.

\section{Wybrane przykłady praktycznych działań i wdrożeń projektów OSŻD}

Organizacja OSZD aktywnie działa w doskonaleniu różnych obszarów funkcjonowania transportu kolejowego, w tym także w zakresie prawa transportowego i przewozów międzynarodowych. Dobitnym tego przykładem jest dążenie do doskonalenia norm prawych i dokumentów związanych z przewozami międzynarodowymi. Istnienie dwóch systemów prawnych, tj. jednolitych wymogów prawnych dla umowy o międzynarodowym transporcie kolejowym (SMGS) oraz Traktatu o międzynarodowym przewozie towarów koleją (CIM) w Azji i Europie wynika $\mathrm{z}$ cech geopolitycznych, gospodarczych i prawnych. Systemy te regulują stosunki między stronami umowy przewozu towarów, ale różnią się znacznie zarówno pod względem formy, jak i w rozumieniu indywidualnych przepisów prawa transportowego, które tworzą różnice w przewozie obejmujące oba systemy [5].

Analiza transgranicznego transportu tych systemów prawnych wykazała, że wiele czasu i wysiłku poświęca się na ponowne wydawanie kolejowych listów przewozowych na przejściach granicznych. Jednocześnie w wielu przypadkach występują różne zakłócenia, błędy, nieścisłości, które powodują opóźnienie ładunku na granicy lub problemy $\mathrm{z}$ jego terminową dostawą do klienta. Istniejące dwa systemy prawne nie sprzyjały rozwojowi przewozów międzynarodowych w komunikacji Europa - Azja - Europa. Wspólny projekt OSZD/ CIT/OTIF zaowocował powstaniem ujednoliconego listu przewozowego CIM/SMGS, który umożliwił transportowi kolejowemu sprawniejsze przekraczanie granic. Zasięg oddziaływania przedstawia rysunek 4 .

List przewozowy CIM/SMGS jest jednolitym listem przewozowym używanym do przewozu towarów do krajów stosujących różne przepisy dotyczące transportu międzynarodowego (SMGS i CIM) i jest wydawany na całą podróż bez ponownej rejestracji w miejscu zmiany prawa przewozowego. Jest uznawany za dokument celny i upraszcza procedury przekraczania granic towarów przewożonych koleją. Obecnie, list przewozowy CIM/SMGS jest używany na kolei 17 krajów OSJD ${ }^{7}$, jednak stosowanie listu przewozowe-

\footnotetext{
${ }^{7}$ Republiki Azerbejdżanu, Republiki Białoruś, Republiki Bułgarii, Węgier, Gruzji, Republiki Kazachstanu, Ludowej Republiki Chin, Republiki Łotewskiej, Republiki Litewskiej, Republiki Mołdowy, Mongolii, Rzeczypospolitej Polskiej, Federacji Rosyjskiej, Republiki Słowackiej, Ukrainy i Republiki Estońskiej.
} 


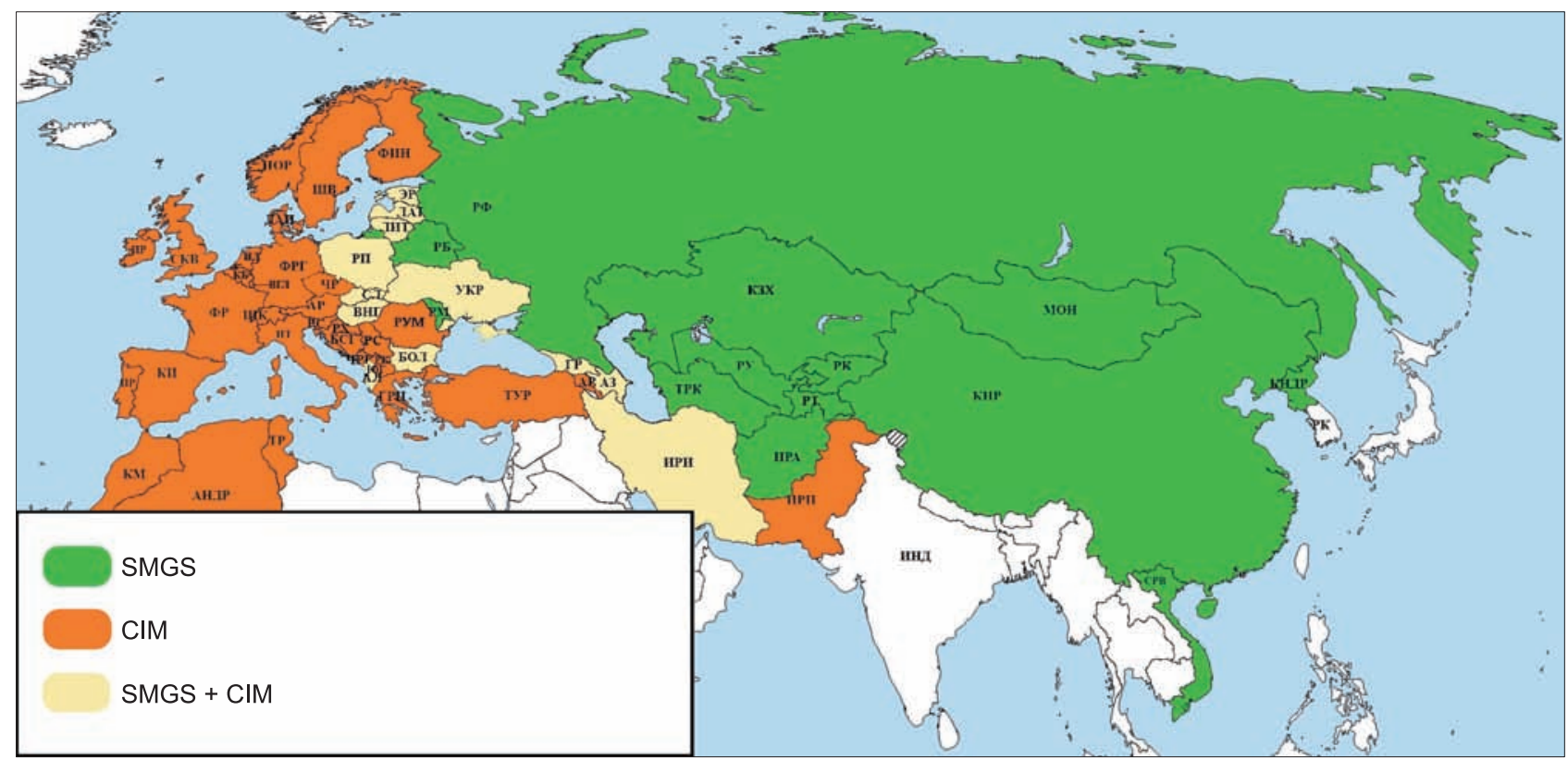

Rys. 4. Obszary zasięgu SMGS i COTIF - Prawne systemy transportowe [5]

go CIM/SMGS jest dobrowolne. Wdrożenie tego listu w praktykę przewozów międzynarodowych przyniosło pozytywne skutki dla transportu kolejowego, między innymi: znaczne skrócenie czasu przestoju pociągów na stacjach granicznych; poprawę jakości usług i obniżenie kosztów transportu; oszczędność czasu przewidzianego na ponowną rejestrację dokumentów na granicach; zmniejszenie kosztów związanych z ponownym wydawaniem dokumentów dotyczących kontynuacji transportu na kolei, na których obowiązuje inne prawo przewozowe; eliminację wielu nieścisłości i błędów popełnionych w wyniku ponownej rejestracji dokumentów przewozowych dla przesyłek; zapewnienie wysokiego poziomu zgodności z normami prawnymi podczas transportu dla ich uczestników; wzrost szybkości dostawy ładunku w wyniku zmniejszenia parkowania $\mathrm{w}$ miejscach ponownej wysyłki; list przewozowy CIM/SMGS jest używany jako tranzytowy dokument celny.

Reasumując, stosowanie listu przewozowego CIM/ SMGS ma znaczenie dla multimodalnego transportu towarów w kierunkach Chiny - Morze Bałtyckie - Europa, Chiny - Morze Kaspijskie - Morze Czarne - kraje europejskie, a także dla dalszego rozwoju współpracy $\mathrm{w}$ dziedzinie transportu ( $\mathrm{w}$ tym transportu kombinowanego i multimodalnego) między krajami Azji i Europy. Przykłady organizacji i kierunków przewozowych wykorzystujących CIM/SMGS przedstawia rysunek 5 .
Drugim, niewątpliwie ważnym obszarem i osiągnięciem $\mathrm{w}$ ostatnich latach jest dążenie do zwiększenia umiejętności i kompetencji pracowników kolei w krajach członkowskich organizacji współpracy kolei. Transport kolejowy szybko się zmienia. Wyzwania związane z cyfryzacją są innowacjami, ekologią, zrównoważonym transportem, nowymi technologiami komunikacyjnymi i procesowymi i wymagają od pracowników kolei ciąłłego doskonalenia wiedzy i umiejętności. Personel kolejowy, jego postawa oraz kompetencje są istotnymi czynnikami konkurencyjności i zwiększania znaczenia transportu kolejowego i między innymi stało się to podstawą do powołania Akademii OSŻD

Działania Akademii OSŻD mają na celu zorganizowanie i metodologiczne wsparcie kształcenia i szkolenia zawodowego $\mathrm{w}$ zakresie stosowania dokumentów regulacyjnych oraz innych dokumentów OSŻD normujących realizację międzynarodowego transportu kolejowego, $\mathrm{w}$ tym $\mathrm{z}$ udziałem innych środków transportu. Nadmienić należy, że udział w pracach Akademii jest dobrowolny. Głównymi celami Akademii OSŻD są między innymi:

- rozwój działań OSŻD w dziedzinie kształcenia i szkolenia zawodowego;

- zapewnienie kontroli nad działalnością organizacji edukacyjnych akredytowanych przez OSŻD w zakresie szkoleń zgodnie ze standardowymi programami i programami szkoleniowymi OSŻD;

\footnotetext{
${ }^{8}$ Decyzją 47 Ministrów Transportu OSJD w dniach 4-7 czerwca 2019 r. w Taszkiencie, Republice Uzbekistanu, powołano Akademię OSŻD. Akademia OSŻD jest wyspecjalizowanym organem z zakresu kształcenia i szkolenia zawodowego, działającym na podstawie regulaminu OSŻD i Regulaminu Akademii OSŻD, który zatwierdzono decyzją XLVIII sesji Ministrów Transportu OSD (Ministerial Meeting 28-30.09.2020).
} 


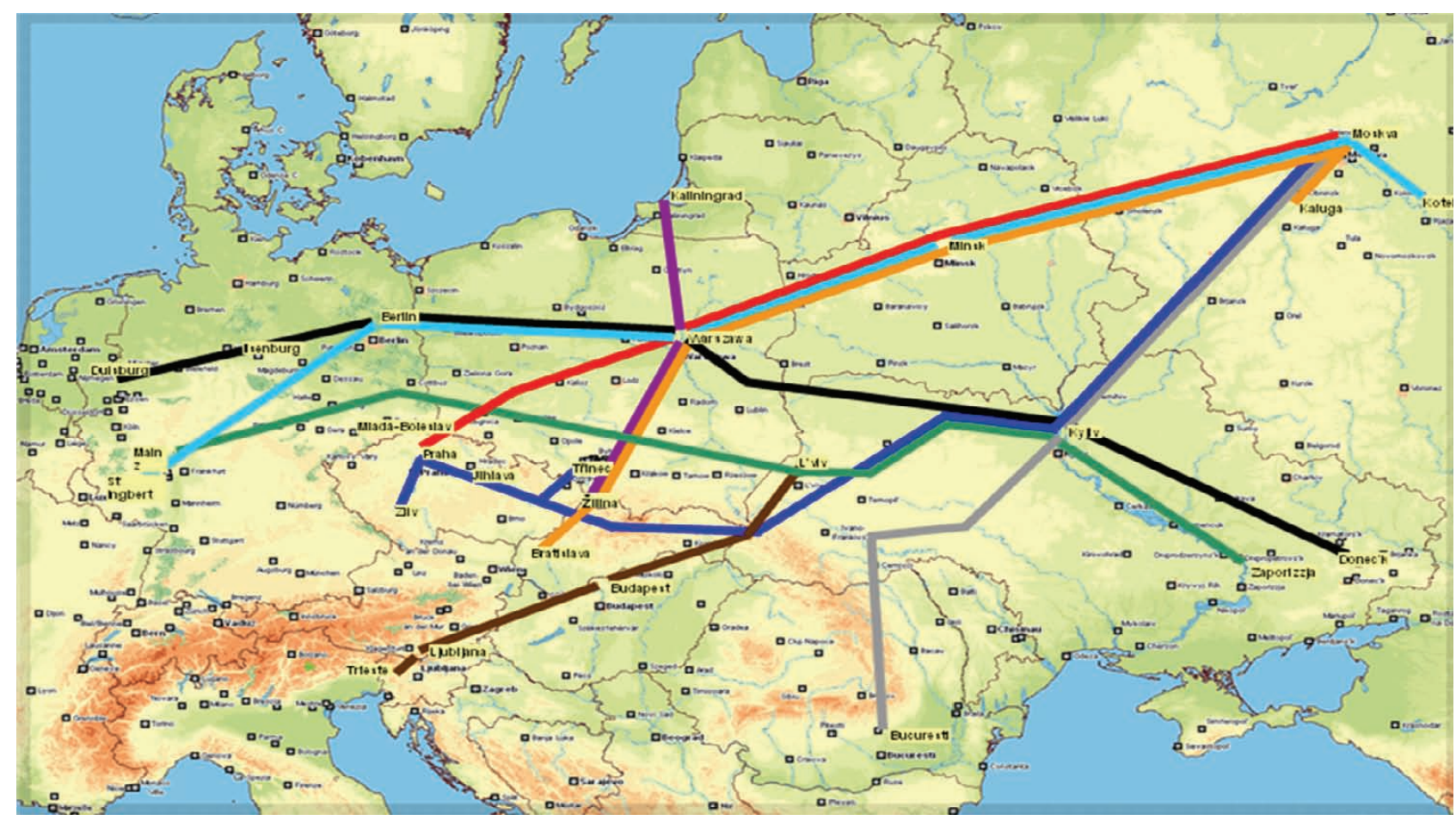

Rys. 5. Organizacja transportu ładunków za pomocą listu przewozowego CIM/SMGS [3]

- koordynacja prac uczestników Akademii OSŻD w zakresie organizacji i realizacji programu i planu prac organów roboczych OSŻD w dziedzinie kształcenia zawodowego;

- rozwój współpracy z organizacjami międzynarodowymi, stowarzyszeniami, instytucjami akademickimi oraz edukacyjnymi w dziedzinie kształcenia i szkolenia zawodowego w celu wymiany doświadczeń i najlepszych praktyk;

- organizowanie konferencji i seminariów w dziedzinie kształcenia zawodowego lub szkolenia pracowników z zakresu organizacji transportu kolejowego;

- monitorowanie jakości stosowania przez uczestników Akademii OSŻD standardowych programów szkoleniowych OSŻD, zatwierdzonych przez OSŻD programów szkoleniowych oraz materiałów szkoleniowych.

Niezależnie od prowadzonej działalności, trwają prace nad uporządkowaniem podstawowych dokumentów Organizacji Współpracy Kolei. Dostrzeżono bowiem potrzebę unormowania podstaw prawnych do wykonywania międzynarodowych przewozów w relacjach euroazjatyckich przez podniesienie statusu prawnego organizacji OSŻD do rangi organizacji międzyrządowej oraz konieczność inkorporacji SMPS i SMGS w porządki prawne państw członkow- skich w drodze ratyfikacji tych umów. U podłoża prac leży potrzeba uwspółcześnienia organizacji, dostosowania struktur do nowych warunków funkcjonowania transportu kolejowego w państwach członkowskich, a przede wszystkim usystematyzowania bazy prawnej do wykonywania międzynarodowych przewozów kolejowych w relacjach pomiędzy państwami członkowskimi OSŻD.

Powołano Tymczasową Grupę Roboczą, której powierzono zadanie przygotowania projektu Konwencji dotyczącej bezpośredniej międzynarodowej komunikacji kolejowej ${ }^{9}$. Od 2010 roku, na wniosek Polski skoncentrowano się na przygotowaniu całościowego projektu Konwencji, która jednocześnie podwyższyłaby status OSŻD do rangi organizacji międzynarodowej, a status umów SMPS i SMGS do rangi umów międzyrządowych. Prace nad projektem Konwencji na poziomie eksperckim OSŻD zakończono w 2015 roku. Oprócz państw członkowskich i aktywnym udziale Chin, aktywny udział w pracach brała także DG MOVE (Directorate-General for Mobility and Transport), zgodnie z zasadą, że prawo transportowe należy do wyłącznych kompetencji UE. Tym samym projekt Konwencji nie koliduje z porządkiem prawnym UE. Od 2016 roku odbywają się Międzynarodowe Konferencje do spraw przyjęcia tekstu Konwencji o bezpośredniej

\footnotetext{
${ }^{9}$ W skład grupy wchodziło kilkanaście państw członkowskich (w tym Polska) oraz Przewodniczący Komitetu OSŻD.
} 
międzynarodowej komunikacji kolejowej. Z powodu pandemii, ostatnia konferencja odbyła w marcu 2019 roku. Przygotowany projekt Konwencji stanowi skuteczną bazę prawną, która zapewni zrównoważoną ochronę prawną wszystkim uczestnikom procesu przewozowego na obszarze państw stron Konwencji i w kompleksowy sposób ureguluje podstawy prawne wykonywania przewozów międzynarodowych. Do zalet nowej Konwencji można zaliczyć:

1. Formalne wyniesienie statusu OSŻD oraz umów SMPS i SMGS na poziom międzyrządowy, analogicznie do Umowy COTIF.

2. Odejście od jednomyślności przy podejmowaniu decyzji na poziomie Narady Ministrów OSŻD.

3. Wpisanie na stałe Warszawy, jako siedziby Komitetu OSŻD.

\section{Uwagi o wyzwaniach przyszłości}

Obecnie jesteśmy świadkami znacznego wzrostu międzynarodowego obrotu towarowego, a także zmian jego trendów. Rosną wielkości kolejowych przewozów kontenerowych między Azją i Europą oraz euroazjatyckie potoki towarowe, realizowane innymi rodzajami transportu. Gwałtowny wzrost handlu internetowego otwiera ogromne możliwości dla organizacji ekspresowych dostaw drobnych przesyłek pocztowych i ładunków mieszanych nie tylko w kontenerach, ale także w wagonach pocztowych, co umożliwiło uruchomienie regularnych, szybkich pocztowych połączeń transportem kolejowym. W 2020 roku transportem kolejowym odprawiono w Rosji prawie 4 tys. ton przesyłek pocztowych, a z Chin do Europy 11 tys. ton przesyłek pocztowych [7]. Przyspieszono procesy przejścia na technologie cyfrowe $\mathrm{w}$ transporcie i logistyce, poczynając od wdrożenia elektronicznych, tranzytowych deklaracji celnych i listów przewozowych po realizację perspektywicznych projektów z zakresu elektronicznej giełdy taboru kolejowego, „elektronicznych pociągów”, np. produkt cyfrowy pociągu kolei rosyjskich [8]. Między Azją - Europą - Azją nastąpiły jakościowe zmiany w całym procesie lądowych dostaw towarów. Obecnie, nie jest to tylko przewóz towarów w kontenerze, lecz kompleksowy produkt logistyczny, który jest realizowany ściśle według rozkładu, $\mathrm{z}$ dokładnie określonym terminem dostawy, w ścisłej integracji z firmami spedytorskimi oraz przewoźnikami „ostatniej mili”. Dobrym przykładem jest nowy produkt logistyczny z Yiw do Londynu - 12 tys. $\mathrm{km} \mathrm{w}$ siedemnaście dób $\mathrm{w}$ korytarzu, który przedstawia rysunek 6.

Kontenerowy tranzyt euroazjatycki jest obszarem silnej konkurencji. Coraz większa liczba interesariuszy występuje w roli operatorów przewozów między Azją i Europą, co oznacza, że azjatyccy i europejscy dysponenci towarów mogą wybierać między operatorami przewozowymi, a konkurencja wymusi wzrost jakości świadczonych usług. Jednym z operatorów jest Euroazjatycki Sojusz Kolejowy (OTLK-EPA) ${ }^{10}$

(rys. 7). Tempo wzrostu przewozów w latach 2016-2020, to ponad 52,6\% z wielkości przewozów na poziomie 100983 TEU w 2016 roku na wielkości na poziomie 546902 TEU w 2020 roku [9].

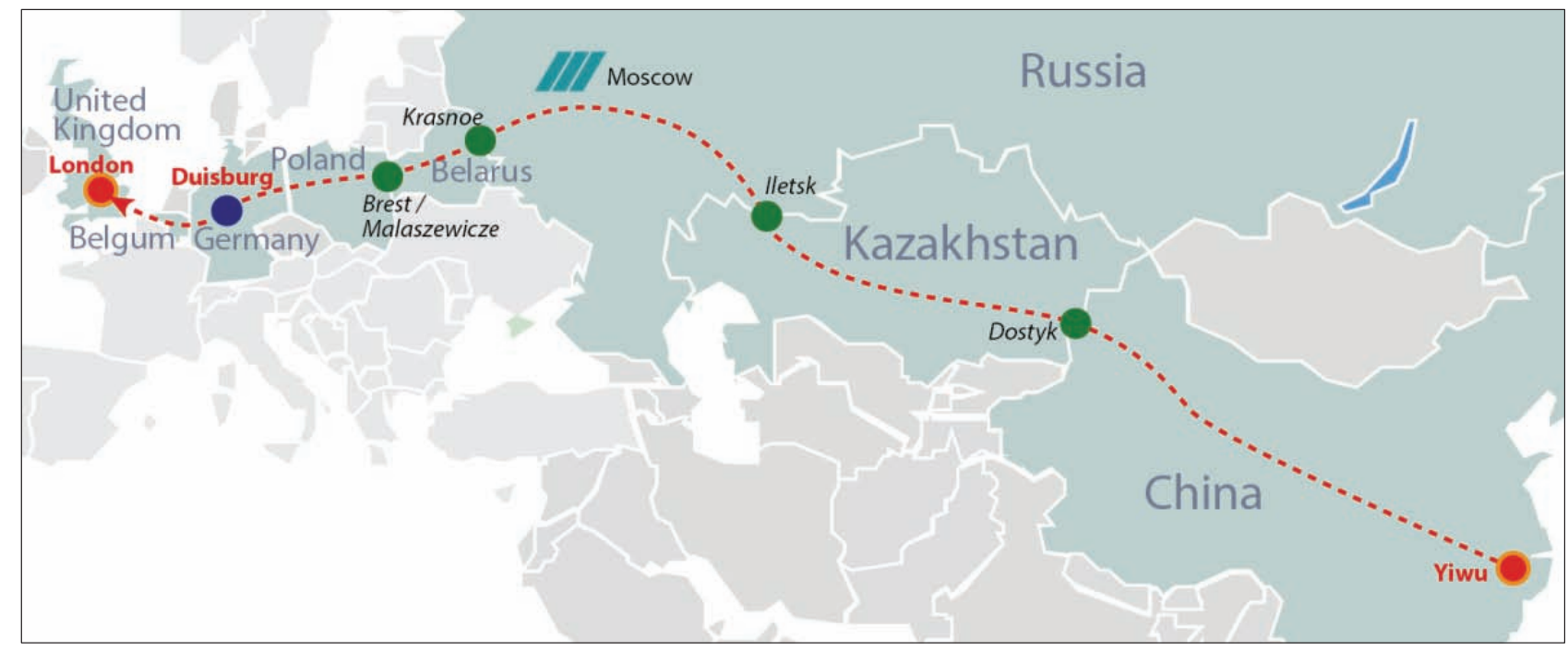

Rys. 6. Przykład kompleksowego produktu [4]

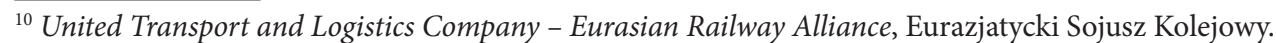




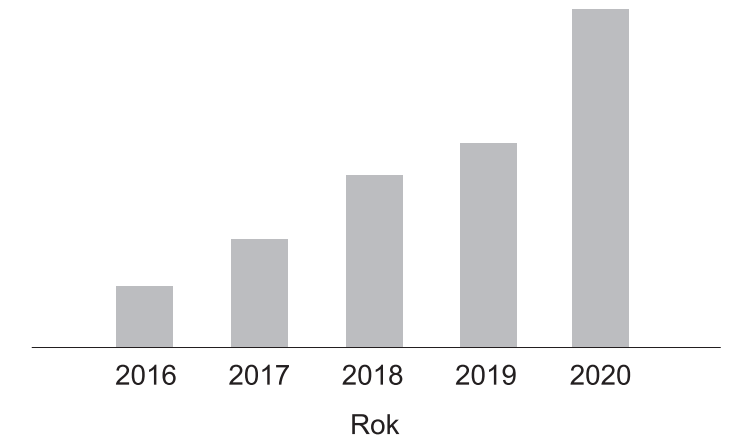

Rys. 7. Wielkości przewozu ładunków OTLK ERA w latach 2016-2020 (TUE) [9]

Należy zwrócić uwagę, że globalne łańcuchy dostaw ewoluują. Czas realizacji staje się ważnym czynnikiem konkurencyjności. Przykładowo, średnia prędkość pociągu to około $900-1000 \mathrm{~km}$ na dobę, średnia prędkość pociągu relacji Czuncin - Duisburg, to $958 \mathrm{~km}$ na dobę, przy odległości ponad 10 tys. km, a w relacji Czendu - Łódź - $890 \mathrm{~km}$ na dobę przy odległości około 9,6 tys. km. Ewolucja rozpoczyna czwartą rewolucję opartą na koncepcji „Przemysł 4.0”, która doprowadza do mariażu technologii analogowych i cyfrowych. Rewolucja postępuje z niespotykaną dotąd szybkością i jest napędzana przez inteligentne, połączone ze sobą technologie. Przekształceniu ulegają dotychczasowe sposoby działania na rzecz nowych rodzajów produktów i usług. Przedsiębiorstwa, w tym kolejowe, wprowadzają nowe modele biznesowe, aby móc w przyszłości dostarczać wartości swoim klientom i rynkom [11].

\section{Zakończenie}

Działalność Organizacji OSŻD, ukierunkowana na rozwój i doskonalenie międzynarodowej komunikacji kolejowej między Europą i Azją oraz zwiększenie efektywności i poziomu jakości świadczonych usług, zachowuje swą aktualność także dzisiaj. Realizując swoją działalność $\mathrm{w}$ dynamicznie zmieniających się warunkach ekonomicznych, rynkowych oraz w reżimie epidemicznych obostrzeń związanych $z$ koronawirusem, OSŻD stale kładzie nacisk na rozwój i doskonalenie warunków sprawnego przewozu towarów kolejami między krajami członkowskimi OSŻD. Działalność ta polega przede wszystkim na doskonaleniu, harmonizacji i ujednoliceniu prawnych i normatywno-technicznych podstaw, a także rozwoju kolejowych korytarzy transportowych, ulep- szaniu taryf przewozowych, usprawnianiu przekraczania granic przy szerszym zastosowaniu jednolitego listu przewozowego CIM/SMGS i jego elektronicznej wersji ${ }^{11}$, co umożliwia skrócenie czasu i obniżenie kosztów przewozów. Łańcuchy dostaw stają się wrażliwe, kruche oraz skracają się, co oznacza, że uproszczenie procedur, stosowanie zharmonizowanych instrumentów i wysiłki na rzecz ujednolicenia norm prawnych, odnoszących się do międzynarodowych kolejowych przewozów tranzytowych, są ważną podstawą poprawy procesów transportowych. Transport kolejowy nie może pozwolić na przerwy w procesie świadczenia usług transportowych. W związku z tym, rozpowszechnianie na przykład listu przewozowego CIM/SMGS, przyczynia się do poprawy konkurencyjności transportu kolejowego na światowych szlakach transportowych. Świadomość zachodzących obecnie zmian $\mathrm{w}$ globalnych procesach, $\mathrm{w}$ tym także ukierunkowanych na ochronę środowiska i energooszczędność, przyczynia się do wzrostu znaczenia kolei OSŻD w rozwoju międzynarodowej komunikacji kolejowej.

\section{Literatura}

1. Antonowicz M.: Organizacja wspótpracy kolei-65 lat, Железные дороги тира, $2021 \mathrm{nr} 4$ s. 20-24.

2. Antonowicz M.: OSŻD - 65 lat w stużbie kolejom świata, Biuletyn OSŻD nr 1 Warszawa 2021, s. 1-9.

3. Aspajewa Z.: Rozszerzenie geografii stosowania listu przewozowego CIM / SMGS. Trasy przewozu na liście przewozowym CIM/SMGS, Materiały Seminarium pt. „Praktyczne zastosowanie listu przewozowego CIM/SMGS", Warszawa 7-8 lipca 2021.

4. Евтимов Е.: Prawne aspekty stosowania listu przewozowego w produktach kolejowych, Materiały Seminarium pt. „Praktyczne zastosowanie listu przewozowego CIM/SMGS", Warszawa 7-8 lipca 2021.

5. Khudoyorov O.: Podsumowanie ram prawnych regulujacych międzynarodowy transport towarowy $z$ wykorzystaniem listu przewozowego CIM/SMGS w państwach członkowskich SMGS, Materiały Seminarium pt. „Praktyczne zastosowanie listu przewozowego CIM/SMGS", Warszawa 7-8 lipca 2021.

6. Informator o OSŻD, Warszawa, 2021.

7. Materiały UPU-Rail Forum, Prezentacja Kolei Chińskich, Berno, lipiec 2021.

8. Materiały UPU-Rail Forum, Prezentacja Poczty Rosyjskiej i Kolei Rosyjskich, Berno, lipiec 2021.

\footnotetext{
${ }^{11}$ Od 1 lipca 2019 r. obowiązuje elektroniczna wersja listu przewozowego CIM/SMGS, dzięki czemu po pierwszej rejestracji znajdują się wszystkie informacje o ładunku, z którym zarówno organy podatkowe, jak i celne, a także inne struktury regulacyjne, mogą jednocześnie pracować.
} 
9. Materiały UPU-Rail Forum, OTLK-EPU, Berno, lipiec 2021.

10. Sprawozdanie z działalności Organizacji OSŻD za 2019 rok, Materiały wewnętrzne OSŻD, Warszawa, 2020.
11. Trębicki P.: Transport w gospodarce cyfrowej 4.0, Materiały niepublikowane, Warszawa, ALK 2021. 